\title{
Population Arrangement of Crambe Plants
}

\author{
Tiago Roque Benetoli da Silva ${ }^{1}$, Beatriz Tomé Gouveia ${ }^{2}$, Ana Claudia Mascarello ${ }^{1}$, \\ Affonso Celso Gonçalves-Júnior ${ }^{3}$, Deonir Secco ${ }^{3}$, Charline Zaratim Alves ${ }^{4} \&$ Reginaldo Ferreira Santos ${ }^{3}$ \\ ${ }^{1}$ Universidade Estadual de Maringá, Maringá, PR, Brazil \\ ${ }^{2}$ Universidade do Federal de Lavras, MG, Brazil \\ ${ }^{3}$ Universidade do Oeste do Paraná, Campus de Marechal Cândido Rondon e Cascavel, PR, Brazil \\ ${ }^{4}$ Universidade Federal do Mato Grosso do Sul, Chapadão do Sul, MS, Brazil \\ Correspondence: Tiago Roque Benetoli da Silva, Departamento de Ciências Agronômicas, Universidade \\ Estadual de Maringá, Avenida Colombo n.5790, CEP: 87020-900, Maringá, PR, Brazil. E-mail: \\ trbsilva@uem.br
}

Received: February 18, 2018

Accepted: April 28, $2018 \quad$ Online Published: September 15, 2018

doi:10.5539/jas.v10n10p282

URL: https://doi.org/10.5539/jas.v10n10p282

\begin{abstract}
Crambe (Crambe abyssinica Hochst) is an alternative raw material for biodiesel production. It is highly resistant to drought and has short growing cycle of 90 to 100 days. This work was conducted in Umuarama city, Parana State, Brazil, in Haplortox typical and aimed to study the effect of row spacing and population densities in the development of crambe in two growing seasons. The experimental design was a randomized block in a $3 \times 3$ factorial scheme with four replications. The treatments consisted of three row spacing $(15,30$ and $45 \mathrm{~cm})$ and three population densities (500 thousand, 750 thousand and 1 million plants per hectare). It was evaluated the thousand grain weight, oil content and grain yield. It can be concluded that high and low spacing plant population lead to smaller yields.
\end{abstract}

\section{Introduction}

Growing economic and environmental concerns, in addition to predictions that non-renewable energy reserves will be depleted in 50 years, have encouraged the search for new energy sources such as biofuels. Research shows the feasibility of using a liquid fuel that is biodegradable, non-toxic, and produced by raw materials (Pitol et al., 2010). The chemical reaction between vegetable oils (fats) and alcohol (ethanol or methanol) creates biodiesel. Currently the industry uses soybean oil as the main source of vegetable oil, followed by sunflower and tallow oils, though according Stachiw et al. (2016) new sources are being studied.

As well as being highly resistant to drought the crambe (Crambe abyssinica Hochst) plant species does well in both warm and cold soils, is resistant to pest and diseases and has an oil content of approximately $35 \%$ by mass, shelled (Pitol et al., 2010). Crambe is an annual upright plant with a height that ranges from 60 to $100 \mathrm{~cm}$. It is grown in several regions of tropical and subtropical climates, with high resistance to water stress, especially in its vegetative stage, has better vegetative growth at temperatures ranging from $15-25{ }^{\circ} \mathrm{C}$, with tolerance to higher temperatures, except while the plant is flowering (Silva et al., 2013).

Research conducted in the Umuarama-PR-Brazil indicates productivity between 1,000 and 2,000 $\mathrm{kg} \mathrm{ha}^{-1}$. In tests performed in the extraction of oil by means of crushing presses obtained yield 25 liters of oil per $100 \mathrm{~kg}$ of grains (Rogério et al., 2012).

Seeding rate is an important factor to be considered in the crop implantation to achieve satisfactory initial plant population and get consistent performance in the field (Stacciarini et al., 2010). The right combination of row spacing and plant density enables the best use of light, water and nutrients by plants (Martin et al., 2012). Braz and Rossetto (2009) reported that seeding rate can influence the establishment and growth of plants during their growth cycle.

The ideal arrangement of plants in the sowing area depends on the intrinsic characteristics of the variety, such as size, growth habit and plant architecture (Bezerra et al., 2009), as well as environmental conditions and management system (Bizinoto et al., 2010). 
Kruger et al. (2014) working with genotypes canola (Hyola 432 and Hyola 61) and plant densities (20, 40, 60 and 80 plants $\mathrm{m}^{-2}$ ), concluded the $0.40 \mathrm{~m}$ spacing employed provided no changes in grain yield in isolation.

Soratto et al. (2011) worked with row spacing of 45, 60, 75 and $90 \mathrm{~cm}$ and plant populations of 25,000, 40,000, 55,000 and 70,000 plants of castor bean per hectare, they found that increase in plant population, regardless of row spacing, the survival of plants decreased, stem diameter, number of racemes per plant and fruits per raceme. Higher yields of grain and oil cultivar FCA-PB were obtained with initial populations between 55,000 and 70,000 plants per hectare in row widths 0.45 to $0.75 \mathrm{~m}$.

Albuquerque et al. (2011) worked with three row spacing of 50, 70 and $90 \mathrm{~cm}$ and three seeding rates of 100 , 140 and 180000 plants ha $^{-1}$ of grain sorghum, in two growing seasons in the northern region of Minas Gerais. It was concluded that by reducing the spacing between rows the grains yield and panicles of sorghum was improved, regardless of plant population.

Debiasi et al. (2007) evaluated the influence of density of 30,60 and $90 \mathrm{~kg} \mathrm{ha}^{-1}$ of viable seeds and velocity (3.2, 5.3, 6.9 and $8.2 \mathrm{~km} \mathrm{~h}^{-1}$ ) seeding in grain yield and components of the oat yield (Avena strigosa Schreb.), in the region of São Gabriel/RS, under conditions of intense grazing, observed fewer panicles per $\mathrm{m}^{2}$ for densities of 30 and $60 \mathrm{~kg} \mathrm{ha}^{-1}$. The higher number of caryopsis per panicle offset this, so that higher yield grains were obtained in these densities. The densities did not significantly affect the 1000 caryopsis.

Given the recent interest in the species the current research about cultivation, liming and fertilization as well as spacing and population density is insufficient. Thus, this study aimed to verify the effect of row spacing and population densities on the development of crambe.

\section{Methods}

The experiment was conducted under field conditions, in Umuarama city, Parana State, Brazil, situated $53^{\circ} 18^{\prime}$ West longitude and $23^{\circ} 47^{\prime}$ South latitude and altitude $430 \mathrm{~m}$. The climate is mesothermal humid subtropical (cfa). The soil is Oxisol dystrophic with a sandy texture (USDA, 1998).

Plots for each treatment consisted of six lines five meters in length, spaced according to each treatment, considered useful area four centerlines, ignoring $0.5 \mathrm{~m}$ at both ends.

Experimental design was a randomized block in a $3 \times 3$ factorial scheme with four replications. The treatments consisted of three spacing between rows $(15,30$ and $45 \mathrm{~cm})$ and three population densities $(500,750$ and 1 million plants per hectare).

Sowing was performed manually in May 2012 and 2013, with crambe FMS-Brilhante. The grinding was done 20 days after sowing leaving in each treatment the number of plants per meter in accordance with the desired density.

Soil fertilization correction was performed according to indications Pitol et al. (2010). With nitrogen topdressing was performed at a dose of $60 \mathrm{~kg} \mathrm{ha}^{-1}$ built next to the seeding line to 20 days after plant emergence, using as urea.

After completing the cycle of about 90 days, the crambe was manually harvested by cutting the shoots of the plants located in $0.5 \mathrm{~m}^{2}$ area of each plot. Impurities were removed from the harvest thus leaving clean grains for later weighing and determination. The mass evaluated was 1,000 grains, and the oil content in the crambe seed was measured by the method of Silva et al. (2015). The data on productivity were converted to $\mathrm{kg} \mathrm{ha}^{-1}$, with correction for the $13 \%$ moisture.

Statistical analysis was performed followed by analysis of variance model, through Sisvar program using the 5\% level of significance. The average of both factors was compared by Tukey test, with the same significance level $(5 \%)$.

\section{Results}

The thousand-grain weight and oil content were not affected by treatments. It is inferred that the distribution of plants in the area not alters the density of the grains (Table 1). 
Table 1. 1,000 grains mass (g), oil content (\%) of crambe seeds under row spacing $(\mathrm{cm})$ and plant population $\left(1,000\right.$ plantas ha $\left.^{-1}\right)$. Umuarama, Paraná State, Brazil, 2012/13

\begin{tabular}{|c|c|c|c|c|}
\hline \multirow{2}{*}{ Treatments } & \multicolumn{2}{|c|}{ 1,000 grains mass $(\mathrm{g})$} & \multicolumn{2}{|c|}{ Oil content $(\%)$} \\
\hline & 2012 & 2013 & 2012 & 2013 \\
\hline \multicolumn{5}{|l|}{ Row espacing $(\mathrm{cm})$} \\
\hline 15 & 8.39 & 7.89 & 30.35 & 31.01 \\
\hline 30 & 7.92 & 7.94 & 30.65 & 32.72 \\
\hline 45 & 8.46 & 8.16 & 31.52 & 31.50 \\
\hline \multicolumn{5}{|c|}{ Population (1000 pl ha $)$} \\
\hline 500 & 8.58 & 8.80 & 30.64 & 31.74 \\
\hline 750 & 8.09 & 8.11 & 30.81 & 31.20 \\
\hline 1000 & 8.09 & 8.10 & 31.07 & 31.09 \\
\hline \multicolumn{5}{|l|}{ F test } \\
\hline Row espacing (R) & n.s. & n.s. & n.s. & n.s. \\
\hline Population $(\mathrm{P})$ & n.s. & n.s. & n.s. & n.s. \\
\hline Interaction $\mathrm{R} * \mathrm{P}$ & n.s. & n.s. & n.s. & n.s. \\
\hline C.V. $(\%)$ & 8.77 & 9.83 & 1.60 & 2.70 \\
\hline
\end{tabular}

Note. Means followed by the same letter in the column and within each parameter and year, do not differ by Tukey test at $5 \%$ level of probability. n.s. and $*=$ not significative at $5 \%$ level of probability. C.V. $=$ Coeficient of variant.

The interaction between the factors was significant as shown in Table 2, the average of the split between row spacing and plant population for grain yield variable.

Table 2. Deployment of meaningful engagement yield crambe grains $\left(\mathrm{kg} \mathrm{ha}^{-1}\right)$ between row spacing $(\mathrm{cm})$ and plant population $\left(1,000\right.$ plantas ha $\left.{ }^{-1}\right)$. Umuarama, Paraná State, Brazil, 2012/13

\begin{tabular}{|c|c|c|c|}
\hline \multirow{2}{*}{ Population $\left(1,000 \mathrm{pl} \mathrm{ha}^{-1}\right)$} & \multicolumn{3}{|c|}{ Row spacing (cm) } \\
\hline & 15 & 30 & 45 \\
\hline \multicolumn{4}{|l|}{2012} \\
\hline 500 & $1,963 \mathrm{~A} \mathrm{a}$ & $2,077 \mathrm{~A} \mathrm{a}$ & $953 \mathrm{~B} \mathrm{~b}$ \\
\hline 750 & $1,655 \mathrm{~A} \mathrm{a}$ & $1,325 \mathrm{~A} \mathrm{~b}$ & $1,844 \mathrm{~A} \mathrm{a}$ \\
\hline 1,000 & $1,752 \mathrm{~A} \mathrm{a}$ & $1,609 \mathrm{~A} \mathrm{ab}$ & $1,439 \mathrm{~A} \mathrm{ab}$ \\
\hline \multicolumn{4}{|l|}{2013} \\
\hline 500 & $1,210 \mathrm{~A} \mathrm{a}$ & $1,324 \mathrm{~A} \mathrm{a}$ & $200 \mathrm{~B} \mathrm{~b}$ \\
\hline 750 & $902 \mathrm{~A} \mathrm{a}$ & $572 \mathrm{Ab}$ & $1,091 \mathrm{~A} \mathrm{a}$ \\
\hline 1,000 & $999 \mathrm{~A} \mathrm{a}$ & $856 \mathrm{~A} \mathrm{ab}$ & $686 \mathrm{~A} \mathrm{ab}$ \\
\hline
\end{tabular}

Note. Means followed by the same letter, uppercase and lowercase on the line in the column, do not differ by Tukey test at $5 \%$ probability.

In the population of 500 thousand plants spaced $45 \mathrm{~cm}$ apart yield was the lowest. This increased spacing and lower density allows the plant to reach its maximum development potential, though the yield per area is small. Within the spacing $15 \mathrm{~cm}$ there was no difference in yield between the densities.

\section{Discussion}

Silva et al. (2013) observed that crambe oil content in seeds hardly has an influence on function of the environment. The rainfall conditions were atypical, with above average rainfall in the year of this experiment, potentially resulting in the lack of change in the thousand grain weight. Oil production values are close to the crop potential, according to Souza et al. (2009) and Rogério et al. (2012) that found that variation of 35 to $45 \%$ oil content.

Pitol et al. (2010) report that yield can be little affected by the spacing, as the plant species is able to compensate for low populations with significant branching. In canola, Kruger et al. (2014) working with genotypes (Hyola 
432 and Hyola 61) and plant densities $\left(20,40,60\right.$ and 80 plants $\left.\mathrm{m}^{-2}\right)$, noted that in the cultivation of $0.40 \mathrm{~m}$ spacing the different densities employed provided no changes in grain yield in isolation. This supports the idea that in this species there is a strong phenotypic plasticity, allowing the offset of effects from low or high densities in crop condition.

Increased population density did not affect yield. Soratto et al. (2011) worked with row spacings and plant populations of castor bean, concluded in plant population, regardless of row spacing, the survival of plants decreased, stem diameter, number of racemes per plant and fruits per raceme.

Debiasi et al. (2007) also found that with the change in spacing oats was no change in yield. In the population density of 500 thousand plants the highest yield was achieved with $30 \mathrm{~cm}$ spacing between rows, and in the population density of 750 thousand plants there was increased yield at $45 \mathrm{~cm}$ spacing. Under these conditions there was a better distribution of plants in the area and therefore greater efficiency in the utilization of sunlight, water and nutrients (Ferrari et al., 2009).

Stacciarini et al. (2010), found that corn at low densities, a significant increase in yield with both the spacing reduction and the increase in population density. Albuquerque et al. (2011) reported an increase in sorghum yield due to the reduction of the spacing. Bezerra et al. (2009) and Bizinoto et al. (2010) report that alterations in plant yield is a function of adaptability to the environment.

Pitol et al. (2000) observed the effect of spacing and planting density on the crambe yield, cv. FMS Brilhante. The smallest gap while providing better closure of the crop and consequently greater ability to compete with weeds. In the second season, this spacing provided less grain yield due to increased shading and later plant lodging. In the present experiment there was good distribution of rainfall throughout the plant cycle, especially early in the development and flowering period, providing ideal conditions for its cultivation.

It can be concluded that both the $15 \mathrm{~cm}$ and the $45 \mathrm{~cm}$ spacing resulted in lower yields of crambe.

\section{Acknowledgements}

Acknowledgment to CNPq for the scholarship granted.

\section{References}

Albuquerque, C. J. B., von Pinho, R. G., Rodrigues, J. A. S., Brant, R. S., \& Mendes, M. C. (2011). Row spacing and sowing density for grain sorghum in semiarid. Bragantia, 70, 278-285. https://doi.org/10.1590/ S0006-87052011000200005

Bezerra, A. A. C., Távora, F. J. A. F., Freire Filho, F. R., \& Ribeiro, V. Q. (2009). Canopy and yield characteristics of a bunch-type cowpea under different population densities. Pesquisa Agropecuária Brasileira, 44, 1239-1245. https://doi.org/10.1590/S0100-204X2009001000005

Bizinoto, T. K. M. C., Oliveira, E. G., Martins, S. B., Souza, S. A., \& Gotardo, M. (2010). Castor bean crop influenced by different population of plants. Bragantia, 69, 367-370. https://doi.org/10.1590/S0006-87052 010000200014

Braz, M. R. S., \& Rossetto, C. A. V. (2009). Sunflower plants growth in accordance to the achenes vigour and sowing density. Ciência Rural, 39, 1989-1996. Retrieved from http://www.scielo.br/pdf/cr/v39n7/ a264cr1519

Debiasi, H., Martins, J. D., \& Missio, E. L. (2007). Grain yield and yield components of black oat (Avena strigosa Schreb.) as affected by seeding rate and velocity. Ciência Rural, 37, 649-655. https://doi.org/ $10.1590 / \mathrm{S} 0103-84782007000300008$

Kruger, C. A. M. B., Silva, J. A. G., Medeiros, S. L. P., Dalmago, G. A., Silva, A. J., Arenhardt, E. G., \& Gewehr, E. (2014). Relations of environments variable and subperiods in yield and content oil in canola. Ciência Rural, 44, 1671-1677. https://doi.org/10.1590/0103-8478cr20121136371

Martin, T. N., Pavinato, P. S., Lorentz, L. H., Zielinski, R. P., \& Refatti, R. (2012). Spatial distribution of sunflower cultivars and the relationship between growth features. Revista Ciência Agronomica, 43, 338-345. https://doi.org/10.1590/S1806-66902012000200017

Pitol, C., Broch, D. L., \& Roscoe, R. (2010). Tecnologia e produção: Crambe. Fundação MS, Maracaju, Brazil.

Rogério, F., Silva, T. R. B., Santos, J. I., \& Poletine, J. P. (2012). Phosphorus fertilization influences grains yield and oil content in crambe. Industria Crops and Products, 41, 266-268. https://doi.org/10.1016/j.indcrop. 2012.04.016 
Silva, T. R. B., Reis, A. C. S., Nolla, A., Arieira, C. R. D., Silva, C. A. T., Gouveia, B. T., ... Arieira, J. O. (2013). Nitrogen top dressing application and growing season of crambe cultivated on two crop years. Journal of Food, Agriculture \& Environment, 11, 1463-1466. Retrieved from http://world-food.net/ download/journals/2013-issue_3\&4/2013-issue_3\&4-environment/e1.pdf

Silva, T. R. B., Rogério, F., Santos, J. I., Poletine, J. P., \& Gonçalves Júnior, A. C. (2015). Oil quantification of crambe seeds calcination method in muffle furnace. Journal of Agronomic Sciences, 4, 106-111. Retrieved from http://www.dca.uem.br/V4N1.htm

Soratto, R. P., Souza-Schlick, G. D., Giacomo, B. R. S., Zanotto, M. D., \& Fernandes, A. M. (2011). Low-height castor bean row spacing and plant population for mechanical harvest. Pesquisa Agropecuária Brasileira, 46, 245-253. https://doi.org/10.1590/S0100-204X2011000300004

Souza, A. D. V., Fávaro, S. P., Ítavo, L. C. V., \& Roscoe, R. (2009). Chemical characterization of seeds and presscakes of physic nut, radish and crambe. Pesquisa Agropecuária Brasileira, 44, 1328-1335. https://doi.org/10.1590/S0100-204X2009001000017

Stacciarini, T. C. V., Castro, P. H. C., Borges, M. A., Guerin, H. F., Moraes, P. A. C., \& Gotardo, M. (2010). Effect of row spacing reduction and increase in population density on agronomic traits of corn. Ceres, 57, 516-519. https://doi.org/10.1590/S0034-737X2010000400012

Stachiw, R., Ribeiro, S. B., Jardim, M. A. G., Possimoser, D., Alves, W. C., \& Cavalheiro, W. C. S. (2016). Potential of biodiesel productin with oil seed native species from Rondônia, Brazil. Acta Amazônica, 46, 81-90. https://doi.org/10.1590/1809-439220101151

USDA (United States Department of Agriculture). (1998). Keys to soil taxonomy. USDA, New York, USA.

\section{Copyrights}

Copyright for this article is retained by the author(s), with first publication rights granted to the journal.

This is an open-access article distributed under the terms and conditions of the Creative Commons Attribution license (http://creativecommons.org/licenses/by/4.0/). 